\title{
Android-Based Test (ABT) to Evaluate Students' Literacy in Madrasah
}

\author{
Jauhar Ali ${ }^{1, *}$ Lailatul Inayah ${ }^{2}$ \\ 1,2 Department of Arabic Education, IAIN Pekalongan, Indonesia \\ *Corresponding author. Email: jauhar.ali@iainpekalongan.ac.id
}

\begin{abstract}
Along with technology development in the digital era, learning evaluation also experienced developments in the tools based on Android. Android is an information system on a smartphone that has been very popular among learners. Muhammadiyah Vocational High School of Kajen utilizes Android as an evaluation tool. The school has implemented Android Based Test (ABT) since 2020. Previously, the school conducted its evaluation using a computer, but it was wasteful of cost, time, and space. The school then develops an Android Based Test (ABT) evaluation tool that facilitates learners and teachers. This research illustrates the implementation of ABT evaluation and its advantages and disadvantages to evaluate students' literacy in learning Arabic at Muhammadiyah Vocational High School of Kajen. This research uses a qualitative descriptive approach. The data was obtained from observations, documentation, and interviews of several teachers and students. This research shows that the implementation of ABT evaluation in Arabic language learning is carried out in three stages, namely preparation, implementation, and assessment. One of the advantages of $\mathrm{ABT}$ is that it makes the assessments more efficient. It also helps students solve problems easier and can be more motivated. The lack of training of IT teachers, server trouble, the need for a constant and stable internet connection, and the need for a reasonably large quota are some of the shortages of this evaluation method. Nonetheless, the findings confirm that technological tools, such as Android can help teachers improve their performance and manage classroom evaluation more effectively.
\end{abstract}

Keywords: Evaluation of learning, Arabic, Android based test (ABT), Madrasa, Literacy.

\section{INTRODUCTION}

Android-based test (henceforth ABT) is an information system used for evaluation and assessment using Android-based applications. Android is an opensource software using a Linux core system for mobile devices based on ARM architecture processors [1]. Today, the media used is one of the most widely used operating systems by smartphone mobile devices. Evaluation is done by displaying questions and answering them on Android media [2]. The number of resources and features provided makes Android applications easy to develop. One of the Androids can be developed for evaluation in the form of an ABT [3], as has been implemented in Muhammadiyah Vocational High School of Kajen named Elib-Muhamka.

Muhammadiyah Vocational High School of Kajen is a vocational school in the Pekalongan district. It has implemented an ABT evaluation since 2019 to take advantage of technological developments, and the average student already has Android. The researcher chose Muhammadiyah Vocational High School of Kajen as the research site because it is the only school implementing Android-based evaluation compared to other schools in the Kajen sub-district.

The implementation of the ABT evaluation in Arabic learning certainly has advantages and disadvantages compared to using paper media for exams or what is called the Paper Based Test (PBT) evaluation [4]. This conventional evaluation has several shortcomings, such as fraud in the evaluation, duplication, and distribution of question texts require higher costs, energy, and time. It can be concluded that the PBT cannot be said to be effective and efficient, so it needs to be updated with a better evaluation system.

Implementation is a part of the evaluation. Implementation is the adjustment of extended activities [5]. Implementation of evaluation is critical and prominent in educational activities. Evaluation is used to 
measure and calculate indicators to see how far the level of achievement of students' success is. Evaluation cannot be separated from the entire process during learning and from teaching activities. Evaluation is a process of activity to assess something. It is a systematic action to determine the condition of an object through measuring instruments whose results can then be compared with specific indicators to obtain conclusions. In general, evaluation is an assessment to find out the value with criteria that have been determined systematically on the process carried out [6].

ABT is considered to facilitate students in answering questions [7]. In addition, it can train students in writing Arabic letters. However, it also has some shortcomings, making it challenging to work on the questions. Students feel less clear in reading the questions. In addition, sometimes, the Hijaiyah letters are reversed [8]. Students must also be more careful in writing answers because it allows answers to be undetected on the server.

Research related to $\mathrm{ABT}$ evaluation in learning Arabic has never been done before. Still, several studies are associated with this research, including:

First, Rian Laksana Putra [9] et al. conducted research aiming to determine whether the implementation of online exams using the Android-based Moodle Learning Management System with the evaluation of the CIPP model at State Vocational High School 1 Jakarta, DPIB Expertise (Modeling Design and Building Information) for class X students has gone well. Their research concluded that the evaluation of the online exam implementation program using the Android-Based Moodle Learning Management System at State Vocational High School Negeri 1 Jakarta from the input aspect, process aspect, and output aspect still needed improvement and follow-up. However, in the context aspect, it has been carried out well. Online exams are carried out well and prepare students' habits for online exams. In addition, online exams can save time in inputting grades by IT staff because they do not have to collect students' answer papers and do not have to check each student's answer sheet, minimizing the possibility of losing the answer sheet. Furthermore, it saves time as the score will immediately come out after the exam.

Second, Sari [10] et al.'s research describes the result of developing an Android-based test on the colligative properties of the solution. The product/application was created using the Android Studio application in .apk format and smartphones. Moreover, its details are described, including every visual appearance. The application is engaging, easy to use, can be accessed offline, and visualizes animated videos. Overall, it can be used to measure students' ability to explain the colligative properties of the solution.

\section{METHODS}

The current research is descriptive qualitative. The data comes from observations, documentation, and interviews with teachers and students at Muhammadiyah Vocational High School of Kajen. The interviews were conducted directly with the informants by exploring the stages of implementing the ABT evaluation and its advantages and disadvantages in learning Arabic [11].

Data analysis was carried out by searching for and arranging interview transcripts, field notes, and other materials collected [12]. This analysis activity is carried out by analyzing data, organizing, dividing into manageable units, synthesizing, looking for patterns, and finding meaning. The data on the implementation of the ABT evaluation in learning Arabic and the advantages and disadvantages will be systematically researched and reported. Overall, the processes are pictured in Figure 1.

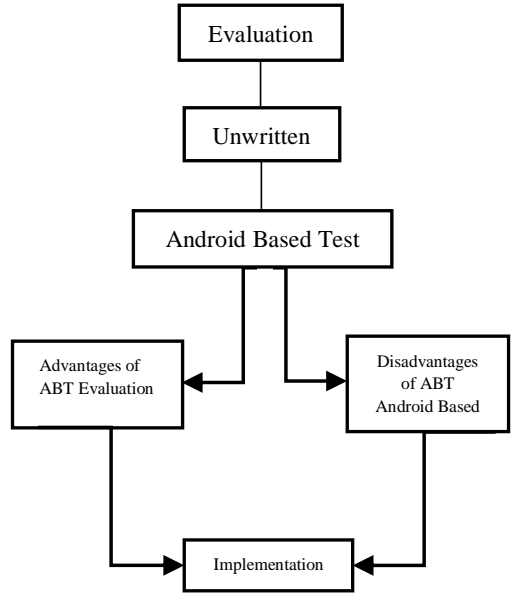

Figure 1 Flowchart of Research Methodology. 


\section{RESULTS AND DISCUSSION}

There are several menus, including the exam menu, token menu, work menu, work reset menu, and test scores menu, which have their respective functions at each evaluation stage based on this Android. Android-based evaluation has three stages: preparation, implementation, and evaluation carried out by students, teachers, and the IT admin [12]. The stages of the ABT evaluation are shown in the following table.

Table 1. Stages in ABT Evaluation

\begin{tabular}{|c|c|c|c|}
\hline Source & Preparation & Implementation & Evaluation \\
\hline Learners & $\begin{array}{l}\text { a. Tools: Android or laptop, internet access. } \\
\text { b. E-Lib App }\end{array}$ & $\begin{array}{l}\text { a. Login with username and } \\
\text { password. } \\
\text { b. Select an Arabic subject in the } \\
\text { Class Advancement } \\
\text { Examination (UKK) menu. } \\
\text { c. Enter the token that has been } \\
\text { given. } \\
\text { d. Students work on test }\end{array}$ & $\begin{array}{l}\text { The results of the scores/ } \\
\text { report cards can be seen on } \\
\text { the E-Lib. }\end{array}$ \\
\hline Teacher & $\begin{array}{l}\text { a. Device: Laptop } \\
\text { b. The teacher makes questions to be tested. } \\
\text { c. The teacher makes grids and scoring. } \\
\text { d. The teacher submits the questions that have } \\
\text { been made to the script team for checking. } \\
\text { e. After passing the script team, the teacher inputs } \\
\text { questions into the Muhamka E-Lib application. } \\
\text { g. Teacher uploads questions } \\
\text { inputted via Android. Wear formal clothes, yet } \\
\text { the material delivery is not maximum. }\end{array}$ & $\begin{array}{l}\text { a. Login with teacher username } \\
\text { and password. } \\
\text { b. Monitoring and supervising } \\
\text { students through the teacher } \\
\text { user. }\end{array}$ & $\begin{array}{l}\text { The assessment will be } \\
\text { carried out by the system } \\
\text { directly, and the teacher } \\
\text { downloads it to their } \\
\text { respective accounts on the } \\
\text { test scores menu and } \\
\text { softcopy for archives. }\end{array}$ \\
\hline IT Admin & $\begin{array}{l}\text { a. Tools: Laptop, Cloud Server, E-Lib Software, } \\
\text { Internet Network } \\
\text { b. Server preparation, both from hardware and } \\
\text { software meaning. }\end{array}$ & $\begin{array}{l}\text { a. Login with the admin account } \\
\text { b. Supervise and ensure the } \\
\text { implementation of the exam } \\
\text { goes well. }\end{array}$ & - \\
\hline
\end{tabular}

According to Table 1, in the preparation stage, students prepare the tools, namely Android cellphones and the Muhamka E-Lib application or link. At the same time, the teacher prepares the exam questions, grids, ELib applications, and laptops. Meanwhile, the IT admin is preparing the hardware and software needed, along with laptop, Cloud Server, E-Lib Software, Internet Network. In the implementation stages, students work on questions after logging into their respective accounts. While at this stage, the teachers monitor and supervise students in working on questions via laptops. Lastly, at the evaluation stage, the assessment process is carried out automatically by the system. Teachers do not have to manually score the students' work. Instead, students' results can be directly downloaded without waiting for a long time.

The ABT certainly has advantages and disadvantages [13]. The advantages and disadvantages of implementing ABT evaluation in learning Arabic at Muhammadiyah
Vocational High School of Kajen based on the results of interviews are as follows.

\section{Advantages}

With ABT, the assessment process becomes more efficient, especially in terms of correcting student answer sheets. Evaluation also saves cost, time, effort, and space. Students also feel that answering questions becomes easier, thus it makes them more motivated [14].

\section{Weaknesses}

The shortcomings found in the implementation are the lack of IT teacher skills, the lack of control in the assessment on attitude aspect, the need for a reasonably large quota, trouble with network and server connections, and the system does not accept Arabic fonts, so that the questions are displayed in the form of an image or screenshots, making it difficult to read [15], [16]. 


\section{CONCLUSION}

Evaluation of the Android Based Test to assess students' literacy in learning Arabic at Muhammadiyah Vocational High School of Kajen follows the stages of preparation, implementation, and evaluation. It is found that there are some advantages and disadvantages this $\mathrm{ABT}$ evaluation. The main advantages are the efficiency in correcting student answer sheets and efficiency in terms of cost, time, energy, and space. Another advantage is that it makes it easier for students to answer questions and makes students more motivated. In contrast, the drawbacks of the ABT evaluation relate to the lack of IT teacher skills, the lack of control in the assessment on attitude aspect, the need for a reasonably large quota, trouble with network and server connections, and the system does not accept Arabic fonts, so that the questions are displayed in the form of an image or screenshots. Therefore, some questions are sometimes difficult to read or blurry.

The researchers hope that the school will be able to develop an ABT evaluation in Arabic subjects, especially in the aspects of mahārahistim $\bar{a}$ ' and mahārahkalām of students so that the assessment/test can also be seen from several factors of skills. Upgrade on adding hijaiyah font to ABT evaluation should also be considered so the evaluation can display the question with hijaiyah font clearly.

\section{AUTHORS' CONTRIBUTIONS}

All authors conceived and designed this study. All authors contributed to the process of revising the manuscript, and at the end, all authors have approved the final version of this manuscript.

\section{REFERENCES}

[1] M. Harmadya, G. M. Aarya asmita, N. K. A. Wirdiani, Rancang Bangun Aplikasi Tryout Ujian Nasional Sekolah Menengah Pertama (SMP) Berbasis Android, Jurnal Ilmiah Teknologi Informasi 6(2), 2015, pp. 108-119.

[2] S. R. Febriani, R. Widayanti, Evaluation of Arabic Learning based on Multiple Intelligences Classroom, International Journal of Arabic Language Teaching (IJALT) 2(02), 2021, pp. 131148.

[3] H. H. Nurhikmah, H. Gani, M. Pratama, H. Wijaya, Development of an Android-based Computer Based Test (CBT) In Middle School. Journal of Education Technology 5(2), 2021, pp. 272-281.

[4] E. Syafrianto, Implementasi Pembelajaran Pendidikana Gama Islam Berwawasan Rekontruksi
Sosial, Al-Tadzkiyyah: Jurnal Pendidikan Islam 6(2), 2015, pp. 217-229.

[5] C. Y. Piaw, Replacing paper-based testing with computer-based testing in assessment: Are we doing wrong?, Procedia-Social and Behavioral Sciences 64, 2012, pp. 655-664.

[6] B. Mahirah, Evaluasi belajar peserta didik (siswa), Idaarah: Jurnal Manajemen Pendidikan 1(2), 2017.

[7] S. Sari, R. Nuralam, C. Z. Subarkah, Developing an Android-Based Test on Colligative Properties of Solution, Journal of Physics: Conference Series, Vol. 1467(1), IOP Publishing, 2020.

[8] M. Rizal, S. Syihabuddin, Evaluasi Pembelajaran Bahasa Arab dengan Memanfaatkan Aplikasi MiSK, Tsaqofiya: Jurnal Pendidikan Bahasa dan Sastra Arab 3(2), 2021, pp. 199-213.

[9] R. L. Putra, A. Maulana, T. Iriani, Evaluasi program pelaksanaan ujian online dengan menggunakan learning management system moodle berbasis android di SMK Negeri 1 Jakarta, Jurnal Pensil: Pendidikan Teknik Sipil 8(1), 2019, pp. 47-54.

[10] S. Sari, R. Nuralam, C. Z. Subarkah, Developing an Android-Based Test on Colligative Properties of Solution, Journal of Physics: Conference Series, Vol. 1467(1), IOP Publishing, 2020.

[11] A. Tanzeh, Metodologi penelitian praktis. 2011.

[12] A. Tanzeh, Metodologi penelitian praktis. 2011.

[13] A. S. Nugroho, Pengembangan Ulangan Berbasis Android Menggunakan Aplikasi Google Form, Jurnal SITECH: Sistem Informasi Dan Teknologi 1(2), 2018, pp. 89-94.

[14] S. V. P. Bhbosale, Z. Multani, Advantages And Disadvantages Of Artificial Intellegence, Aayushi International Interdisciplinary Research Journal, 2020, pp. 227-230.

[15] Mahfudin, Sidik, A. Agus, M. I. Dacholfany, Implementasi Evaluasi Pembelajaran Berbasis Android, Poace: Jurnal Program Studi Adminitrasi Pendidikan 1(1), 2021, pp. 1-11.

[16] R. L. Putra, A. Maulana, T. Iriani, Evaluasi program pelaksanaan ujian online dengan menggunakan learning management system 
moodle berbasis android di SMK Negeri 1 Jakarta, Jurnal Pensil: Pendidikan Teknik Sipil 8(1), 2019, pp. 47-54.

[17] A. S. Nugroho, Pengembangan Ulangan Berbasis Android Menggunakan Aplikasi Google Form, Jurnal SITECH: Sistem Informasi Dan Teknologi 1(2), 2018, pp. 89-94. 